\title{
JUVENILE POLYPOSIS SYNDROME IN A YOUNG PATIENT: A RARE CASE REPORT
}

\author{
Agrawal $Y^{1^{*}}$, Shah $R^{1}$, Joshi $B R^{2}$, Kattel $V^{3}$
}

\section{Affiliation}

1. Assistant Professor, Department of Pathology, B.P. Koirala Institute of Health Sciences

2. Assistant Professor, Department of Surgery, B.P. Koirala Institute of Health Sciences

3. Assistant Professor, Department of Internal Medicine, B.P. Koirala Institute of Health Sciences

\section{ARTICLE INFO}

\section{Article History}

Received : 14 October, 2017

Accepted : 21 August, 2018

Published : 31 August, 2018

(C) Authors retain copyright and grant the journal right of first publication with the work simultaneously licensed under Creative Commons Attribution License CC - BY 4.0 that allows others to share the work with an acknowledgment of the work's authorship and initial publication in this journal.

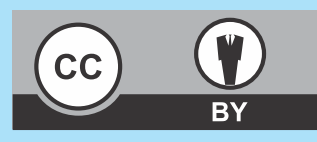

\section{CR 19}

DOI: http://dx.doi.org/10.3126/bjhs.v3i2.20968

\author{
* Corresponding Author \\ Dr Yamuna Agrawal \\ Assistant Professor \\ Department of Pathology \\ B.P. Koirala Institute of Health Sciences Nepal \\ Email: yamunaagrawal@yahoo.com \\ ORCID: https://orcid.org/0000-0003-0617-0548
}

\section{Citation}

Agrawal Y, Shah R, Joshi BR, Kattel V. Juvenile Polyposis Syndrome in A Young Patient: A Rare Case Report. BJHS 2018;3(2)6:492-494.

\section{ABSTRACT \\ Introduction}

Juvenile polyposis syndrome prevalence is 1 in 16,000 to 1 in 100,000 which usually present at the age of 20 years. The tumor is likely to change into malignant condition in $20 \%$ of cases. Here we present this rare syndrome in a 16-year boy.

\section{KEYWORDS}

Hamartomatous polyps, juvenile polyposis syndrome, malignant. 


\section{INTRODUCTION}

Juvenile polyposis syndrome is a rare autosomal dominant disease characterized by different size of polyps, most commonly seen in the colorectal segment of large intestine. ${ }^{1}$ The term "juvenile" indicates for the type of polyp not the age of the patient when the polyp develops hence it can be seen in any age group. ${ }^{2}$ More than $20 \%$ of Juvenile polyposis syndrome patients are found to have inborn defect of different organs like Meckel's diverticula with umbilical fistula, undescended testes, unilateral renal agenesis, split uterus, arterionevoushaemangiomas, stenosis of the pulmonary valve, macrocephaly and intermittent porphyria. ${ }^{3}$

In 1975 the diagnostic criteria for juvenile polyposis syndrome was established. This criteria was revised by Jass et.al. ${ }^{4}$ in 1988 mentioning one of following three criteria must be present:

1. $>5$ juvenile polyps in the large intestine or/and

2. Multiple juvenile polyps throughout the gastrointestinal tract or/and

3. Any number of juvenile polyps with a family history of juvenile polyposis

Positive family history has been associated with $20-50 \%$ of affected patients. ${ }^{3}$ Children with Juvenile polyposis are susceptible to gastrointestinal cancers. ${ }^{5}$

The common presentations are anemia most commonly due to chronic recurrent gastrointestinal bleeding, and diarrhea however some cases had been associated with surgical abdomen like rectal prolapse and intussusception, or medical complications like protein losing enteropathy, starvation and malnutrition. ${ }^{6}$

\section{CASE REPORT}

A 16 year old boy presented with anemia, hypoalbumenia and bleeding per rectum associated with mass coming out per anus for 2 to 3 years. He had alternating diarrhea and constipation with episodic mild abdominal pain. Colonoscopy showed multiple polyps of varying size of both sessile and pedunculated in the rectum and entire colon. Polyps from rectum were sent for histopathological examination revealing benign adenoma. Clinical diagnosis of Familial Adenomatous Polyposis was made and counseled for pan-colectomy.

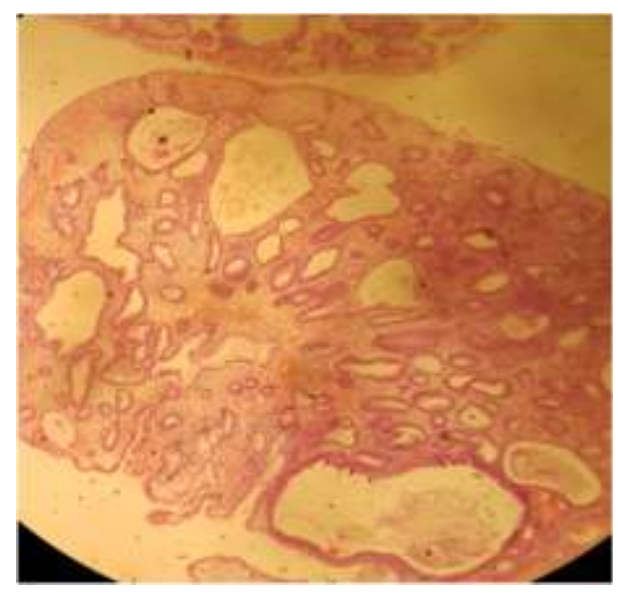

(Magnification 10X)

Figure 1: Low power view reveals polypoidal tissue having cystic like glands with budding and branching.
Macroscopy examination on cut opening of specimen multiple colorectal polyps of varying sizes on the mucosal surface was present. The outer surface of polyp was glistening. It was smooth to touch. Cut surface revealed solid gray white to tan red with few cystic spaces contains jelly like material of size ranging from 0.1 to $0.2 \mathrm{~cm}$.

Microscopy examination of the representative section from entire tissue showed multiple polypoidal tissue revealing tortous gland with budding and branching. (Figure 1) The glands were lined by mucus secreting columnar cells and contain eosinophilic material. The stroma between the glands contained acute and chronic inflammatory cells as well as granulation tissue and hemorrhage. The overlying lining epithelium was partly eroded and erosion free areas were lined by tall columnar cells. (Figure 2 and 3 ) Diagnosis of Juvenile Polyposis Syndrome was made on the basis of histopathology.

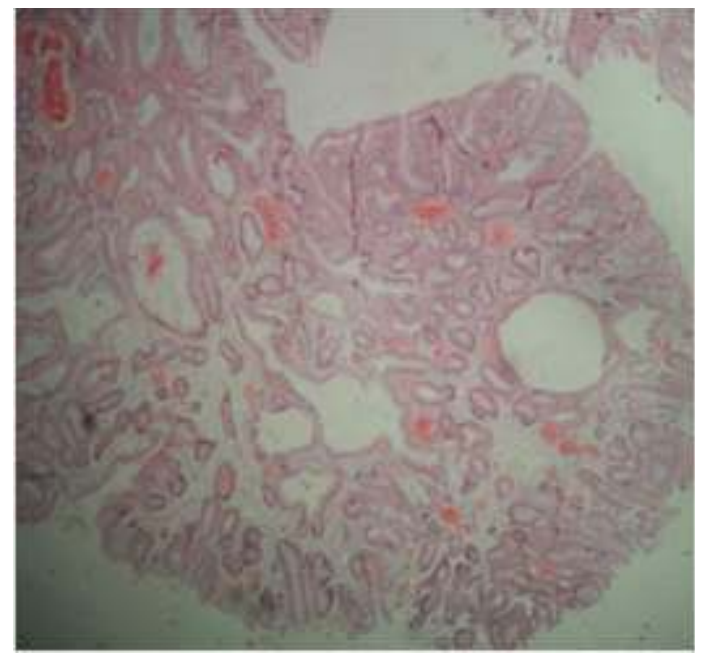

(Magnification 10X)

Figure 2: Low power view reveals polypoidal tissue having cystic like glands with budding and branching.

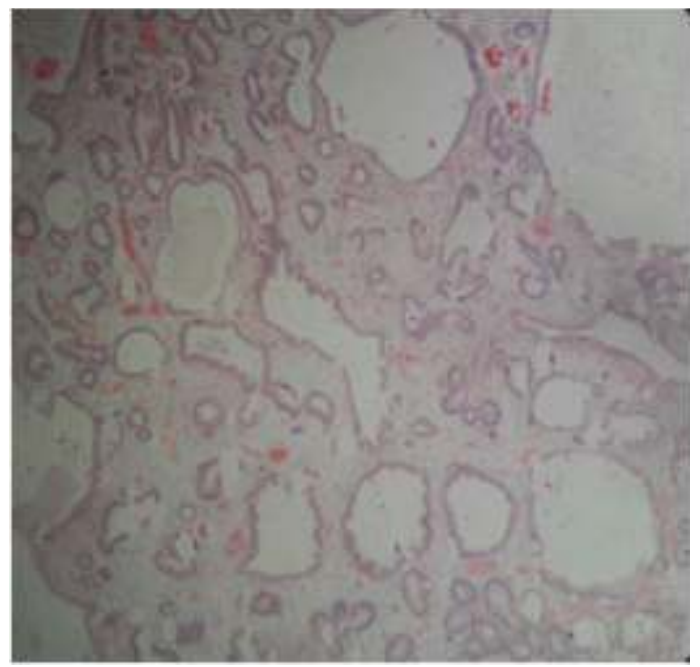

(Magnification 40X)

Figure 3: High power view reveals glands lined by mucus secreting columnar cells. Stroma is edematous and inflammatory cells infiltrates with granulation tissue. 


\section{DISCUSSION}

Juvenile polyposis syndrome is an autosomal dominant condition diagnosed on occurrence hamartomatous gastrointestinal polyps. Patients with juvenile polyposis syndrome are likely to carry gene carriers to various types of tumors. The hamartomatous polyps may turn into malignant lesions in approximately $20 \%$ of cases. ${ }^{7}$ Juvenile polyposis syndrome demonstrated different heterozygous mutations most commonly SMAD4 and BMPR1 on chromososme 10q21 located on chromosome 18q21 respectively. ${ }^{8}$ Evidence of mutation of SMAD4 gene in the family with one member especially siblings or children affected has theoretical risk of being carriers of $50 \%{ }^{9}$. Molecular diagnostics is to optimize prevention, early diagnosis and management at the family level as the chances of malignant transformation is very high.

In our patient there was a family history of rectal polyp and had history of malignancy to cousin. In case of positive family history like the case routine screening colonoscopy is recommended from the age of $10-12$ years, every 2 years until age 40 or beyond if we had screened for genetic mutation. As the mutation detection was out of scope in our settings we strongly recommend colonoscopy screening among all relatives at high risk. ${ }^{9}$

The occurrence of juvenile polyposis syndrome is between 1 in 16,000 and 1 in 100,000. ${ }^{10}$ Majority of patient develop symptoms by the time of 20 years old. The polyps for unknown reason are most often grow in the large intestine (colon) and rectum as in our case however rare growth in the stomach and the small intestine has been documented. ${ }^{10}$

Macroscopically it varies in size from $5 \mathrm{~mm}$ to $50 \mathrm{~mm}$ and has spherical, lobulated and pedunculated appearance with surface erosion. Microscopically a juvenile polyposis is

\section{REFERENCES}

1. Lodewijk A.A. Brosens, W. Arnout van Hattem, MarnixJansen, Wendy W.J. de Leng, Francis M. Giardiello and G. Johan A. Offerhaus. Gastrointestinal Polyposis Syndromes. Current Molecular Medicine 2007; 7: 29-46. https://dx.doi.org/:10.2174/156652407779940404

2. An introduction to juvenile polyposis syndrome. www.stmarks hospital.nhs.uk/wp-content/juvenile-polyposis-syndrome-JPS.pdf

3. Manfredi M: Hereditary hamartomatous polyposis syndrome: understanding the disease risks as children reach adulthood. GastroenterolHepatol (N Y) 2010; 6: 185-196.https://doi.org/ 10.1186/1750-1172-9-101

4. Jass JR, Williams $C B$, Bussey $H J$, Morson $B C$ : Juvenile polyposis - a precancerous condition. Histopathology 1988; 13: 619-630. PMID: 2853131

5. Vargas-Gonzalez R, de la Torre-Mondragon L, Aparicio-Rodriguez JM, Paniagua Morgan F, Lopez- Hernandez G, Garrido-Hernandez MA, Nunez- Barrera S. Juvenile polyposis of infancy associated with paracentric inversion and deletion of chromosome 10 in a Hispanic patient: a case report. PediatrDevPathol 2010; 13: 486-91. http://doi.org/10.2350/10-01-0791-cr.1

6. Yi-Han Hsiao, Chin-Hung Wei, Szu-Wen Chang, Lung Chang, Yu-Wei Fu, Hung-Chang Lee, Hsuan-Liang Liu, Chun-Yan Yeung. Juvenile polyposis syndrome: An unusual case report of anemia and gastrointestinal bleeding in young infant. Hsiao et al. Medicine 2016; 95:37.https://dox.doi.org/10.1097/MD.0000000000004550 characterized bypresence of abundant of inflammatory cells at edematous laminapropria with and cyst like glands lined by cuboidal to columnar epithelium that has reactive changes within the dilated gland. ${ }^{11}$

These polyps may be the seat of focus of dysplasia and in some cases; true adenomas were described in their vicinity. ${ }^{11}$ Our patient macroscopically and microscopically showed as solitary juvenile polyposis syndrome, neither a contingent of adenomas or dysplasia.

The treatment depends on the clinical presentation, location and number of polyps. Routine colonoscopy screening with endoscopic polypectomyif needed is the most effective treatment of solitary polyps. However surgical intervention like subtotal or total gastrectomy or pan colectomy is recommended in case of multiple number of polyps that minimize the symptoms and to prevent malignancy transformation in future. ${ }^{12}$

Pan colectomy in our patient was definitive cure for rectal bleeding and prevention of development of malignancy.

\section{CONCLUSION}

Juvenile polyposis syndrome is a rare disease usually seen among teens but can be fatal or incurable that can be prevented by surgical intervention. The screening of subclinical disease in family with colonoscopy is beneficial.

\section{CONFLICT OF INTEREST}

No conflict of interest

\section{FINANCIAL DISCLOSURE}

None

7. Handra-Luca A, Condroyer C, de Moncuit C, Tepper M, Flejou JF, Thomas G, Olschwang S. Vessels morphology in SMAD4 and BMPR1 A-realated juvenile polyposis. Am J Med Genet A. 2005; 138A (2): 113-7. PMID: 16152637

8. Howe JR, Roth S, Ringold JC, Summers RW, Jarvinen HJ, Sistonen P, Tomlinson IP, Houlston RS, Bevan S, Mitros FA, Stone EM, Aaltonen LA. Mutation in the SMAD4/DPC4 gene in juvenile polyposis. Science. 1998; 280 (5366): 1086-8. PMID: 9582123

9. Mounia El Yousfi, BahijaBenyachou, Adillbrahimi, LailaChbani, AfafAmarti. Young patient with juvenile polyposis syndrome: A case report. Open journal of Gastroenterology. 2012; 2: 105-108. http://dx.doi.org/10.4236/ojgas.2012.23022

10. Cleveland Clinic. Genomic Medicine Institute: Juvenile polyposis syndrome. https://my.clevelandclinic.org/health/articles/Juvenilepolyposis-syndrome [assessed on 2017 March 30].

11. Lodewijk AA Brosens, Danielle Langeveld, W Arnout Van Hattem, Francis M Giardiella, G Johan A Offerhaus. Juvenile polyposis syndrome. World J Gastroenterol. 2011; 17(44): 4839-4844.http:// dx.doi.org/10.3748/wjg.v17.i44.4839

12. Samuel Essoun, Jonathan CB Dakubo, Antoinette A Bediako-Bowan. Juvenile polyposis syndrome - Two case reports. Journal of case reports. 2014; 4(2): 395-399.http://dx.doi.org/10.17659/ 01.2014 .0100 